\title{
An Ethanolic Extract of Boehmeria caudata Aerial Parts Displays Anti-inflammatory and Anti-tumor Activities
}

\section{(우요 $\odot$}

Authors

Paula Pereira de Paiva1, 2, 3D, Fabiana Regina Nonato², Ana Lúcia Tasca Gois RuizºD, Ilza Maria de Oliveira Sousa2, 3 , Rafael Rosolen Teixeira Zafred ${ }^{1,2}$, Diogo Noin de Oliveira ${ }^{3}$, Rodrigo Ramos Catharino ${ }^{3}$, Mary Ann Foglio ${ }^{3}$, João Ernesto de Carvalho ${ }^{3}$

\section{Affiliations}

1 Institute of Biology, University of Campinas, Campinas, Brazil

2 Chemical, Biological and Agricultural Research Center, (CPQBA), University of Campinas, Paulínia, Brazil

3 Faculty of Pharmaceutical Sciences, University of Campinas, Campinas, Brazil

Key words

Boehmeria caudate, Urticaceae, inflammation, antineoplastic agents, Ehrlich tumor carcinoma, drug screening assays

$\begin{array}{ll}\text { received } & 20.11 .2019 \\ \text { revised } & 18.01 .2020 \\ \text { accepted } & 22.01 .2020\end{array}$

\section{Bibliography}

DOI https://doi.org/10.1055/a-1111-9907

Planta Med Int Open 2020; 7: e17-e25

(c) Georg Thieme Verlag KG Stuttgart · New York

ISSN 2509-9264

\section{Correspondence:}

Dra. Paula Pereira de Paiva

Faculty of Pharmaceutical Sciences, University of Campinas, Cândido Portinari, 200

13083-871, Cidade Universitária Zeferino Vaz

Campinas SP

Brazil

Tel.: + 55 (19) 35217715

paula.p21@gmail.com
Aupporting Information for this article is available online at http://www.thieme-connect.de/products.

\begin{abstract}
The tumor microenvironment presents several therapeutic targets, with inflammation being one of them. In search of new drugs, plants have shown to be an effective source of potent anti-inflammatory and anticancer agents. This study aimed to evaluate the antitumoral and inflammatory activities of Boehmeria caudata aerial parts extract. Bioguided in vitro antiproliferative screening showed that phenanthroquinolizidine obtained from the aerial $B$. caudata ethanolic extract had a straight relationship with activity. Moreover, the orally administered ethanolic extract reduced Ehrlich solid tumor growth and displayed an anti-inflammatory effect in both evaluated experimental models (carrageenan-induced paw edema and croton oil-induced ear edema). These results suggest that the antitumor activity of the ethanolic extract could be explained by antiproliferative effects associated with anti-inflammatory action.
\end{abstract}




$\begin{array}{ll}\text { ABBREVIATIONS } \\ \text { AE: } & \text { aqueous extract } \\ \text { AEF: } & \text { alkaloid enriched fraction } \\ \text { CG: } & \text { carrageenan } \\ \text { COX: } & \text { cyclooxygenase } \\ \text { DE: } & \text { dichloromethane extract } \\ \text { EE: } & \text { ethanolic extract } \\ \text { HaCat: } & \text { immortal keratinocyte non-tumor human line } \\ \text { i.p.: } & \text { intraperitoneal } \\ \text { LOX: } & \text { lipoxygenase } \\ \text { MCF-7: } & \text { breast human tumor cell line } \\ \text { NCI-H460: } & \text { non-small cell lung human tumor line } \\ \text { o.r.: } & \text { oral } \\ \text { RTW: } & \text { relative tumor weight } \\ \text { TPA: } & \text { 12-O-tetracanoylphorbol lipoxygenase-13-ac- } \\ & \text { etate } \\ \text { TGI: } & \text { total growth inhibition } \\ \text { t.t.: } & \text { topical treatment } \\ \text { U251: } & \text { glioma human tumor cell line } \\ & \end{array}$

\section{Introduction}

Considered one of the hallmarks of cancer, inflammation substantially contributes to the development and progression of malignancies [1]. Many plant-derived natural products have been described as potent anti-inflammatory and anticancer agents, in which they provide alternative strategies for the development of new drugs [2-4].

Boehmeria caudata Sw (Urticaceae) aerial parts extract had showed a promising antiproliferative effect (total growth inhibition lower than $0.25 \mu \mathrm{g} \mathrm{mL}^{-1}$ ) in a preliminary screening done by our research team [5]. This species is widely spread across the neotropical region, that is, throughout Central and South America [6]. Found in the Southeast and Southern regions, and in the State of Mato Grosso do Sul in Brazil, B. caudata is well known as "lixa-da-folha-larga" and "assa-peixe" [7].

Despite the traditional usage, there is only one study aiming at the investigation of the pharmacological potential of $B$. caudata that describes the cytotoxic activity of $B$. caudata stem wood ethanolic extract upon human epidermoid carcinoma of the nasopharynx [8]. Considering the Boehmeria genus, there is evidence of anti-inflammatory and antitumor effects in addition to the presence of phenanthroquinolizidine alkaloids, such as cryptopleurine, in some extracts [9-14]. Therefore, the present study prompted the in vitro and in vivo evaluation of anti-inflammatory and antitumor effects of the ethanolic extract of $B$. caudata aerial parts.

\section{Results and Discussion}

$D E, E E$, and $A E$ of $B$. caudata aerial parts and $A E F$ were evaluated on four human cell lines (one non-tumor and three tumor cell lines) using doxorubicin as a positive control. Expressed as the sample concentration required for $\mathrm{TGl}\left(\mu \mathrm{g} \mathrm{mL}^{-1}\right)$, the extracts and fraction were classified as active when TGI $\leq 50 \mu \mathrm{g} \mathrm{mL}^{-1}$ against at least two tumor cell lines in a panel of three tumor cell lines [15]. DE weakly inhibited breast (MCF-7, TGI: $35.26 \mu \mathrm{gL}^{-1}$ ) and lung (NCl-H460, TGI: $\left.38.19 \mu \mathrm{g} \mathrm{m}^{-1}\right)$ tumor cell lines while AE showed weak and moderate activity on glioma (U251, TGI: $27.73 \mu \mathrm{g} \mathrm{mL}^{-1}$ ) and lung ( $\mathrm{NCl}-\mathrm{H} 460$, TGI: $6.67 \mu \mathrm{g} \mathrm{mL}^{-1}$ ) tumor cell lines in the order given. The most active samples were $\mathrm{EE}$ and $\mathrm{AEF}$, which potently inhibited $\left(\mathrm{TGl}<0.25 \mu \mathrm{g} \mathrm{mL}^{-1}\right)$ the three tumor cell lines. Further, all extracts inhibited the non-tumor cell line HaCat ( $\triangleright$ Table 1$)$.

Using TLC with Dragendorff reagent ( $\mathbf{F i g .} \mathbf{1} \mathbf{a}-\mathbf{m})$, the expectable presence of alkaloids was confirmed in the $B$. caudata aerial parts ethanolic extract by the regard of fluorescent spots under UV, which were brownish due to the Dragendorff reagent. Acid-based extraction of EE afforded the AEF ( $\triangleright \mathbf{F i g} \mathbf{~} \mathbf{1 j}-\mathbf{m})$. Thus, the presence of alkaloids in both EE and AEF could explain the alikeness in the antiproliferative profile of these samples.

High-resolution electrospray ionization mass spectrometry (HRESI-MS) analysis of AEF allowed for the putative identification and relative quantification of five phenanthroquinolizidine alkaloids (cryptopleurine, boehmeriasin A, boehmeriasin B, julandine, hydroxycryptopleurine), one quinolizidine alkaloid [3-(4-hydroxyphenyl)-4(3-methoxy-4-hydroxyphenyl)-3,4-dehydroquinolizidine], and two acetophenone alkaloids (3,4-dimethoxy- $\omega$-(2'-piperidy 1 ) acetophenone and 2',4'dimethoxyacetofenone) ( $>$ Table 2). Except for cryptopleurine, seven alkaloids were identified for the first time in B. caudata aerial parts extract.

Due to the antiproliferative effect of EE, the anti-inflammatory $[18]$ and antitumor $[8,11,18]$ activities of the identifiable alkaloids ( $\triangleright$ Table 2 ), and the availability of test material, further assessments were conducted on in vivo antitumor and anti-inflammatory models to establish the in vivo correlation between the two activities.

Following the acute toxicity protocol [19], the higher administrated dose of EE that promotes no clinical adverse effects was determined using two different routes of administration. Neverthe-

- Table 1 B. caudata extracts in vitro antiproliferative activity (TGI, $\mu \mathrm{g}$ $\mathrm{mL}^{-1}$ ).

\begin{tabular}{|l|c|c|c|c|}
\hline & \multicolumn{4}{|c|}{ Cell lines $^{a}$} \\
\hline $\begin{array}{l}\text { Sam- } \\
\text { ples }\end{array}$ & U251 & MCF-7 & NCI-H460 & HaCat \\
\hline DE & $90.50 \mathrm{I}$ & $35.26 \mathrm{~W}$ & $38.19 \mathrm{~W}$ & $35.57 \mathrm{~W}$ \\
\hline $\mathrm{EE}$ & $<0.25 \mathrm{P}$ & $<0.25 \mathrm{P}$ & $0.66 \mathrm{P}$ & $<0.25 \mathrm{P}$ \\
\hline $\mathrm{AE}$ & $27.73 \mathrm{~W}$ & $63.57 \mathrm{I}$ & $6.67 \mathrm{M}$ & $7.94 \mathrm{M}$ \\
\hline $\mathrm{AEF}$ & $<0.25 \mathrm{P}$ & $<0.25 \mathrm{P}$ & $0.66 \mathrm{P}$ & $<0.25 \mathrm{P}$ \\
\hline DOXO & $2.66 \mathrm{P}$ & $3.69 \mathrm{P}$ & $>25 \mathrm{~W}$ & $19.41 \mathrm{~W}$ \\
\hline
\end{tabular}

TGI: total growth inhibition after $48 \mathrm{~h}$ exposition. TGl values were calculated by nonlinear regression analysis using ORIGIN 8.0 (OriginLab Corporation). aHuman tumor cell lines: U251 (glioma), MCF-7 (breast), NCl-H460 (lung, non-small cells); human non-tumor line: HaCat (immortal keratinocyte). DE: dichloromethane extract, EE: ethanolic extract, AE: aqueous extract; AEF: alkaloid enriched fraction; DOXO: doxorubicin (positive control). CSIR's criteria: inactive (I, TGI $\left.>50 \mu \mathrm{g} \mathrm{mL}^{-1}\right)$, weak activity $(\mathrm{W}, 15 \mu \mathrm{g}$ $\left.\mathrm{mL}^{-1}<\mathrm{TGI}<50 \mu \mathrm{g} \mathrm{mL}^{-1}\right)$, moderate activity $(\mathrm{M}, 6.25 \mu \mathrm{g}$ $\left.\mathrm{mL}^{-1}<\mathrm{TGl}<15 \mu \mathrm{g} \mathrm{mL}^{-1}\right)$, and potent activity $\left(\mathrm{P}, \mathrm{TGl}<6.25 \mu \mathrm{g} \mathrm{mL}^{-1}\right)$ [15]. 

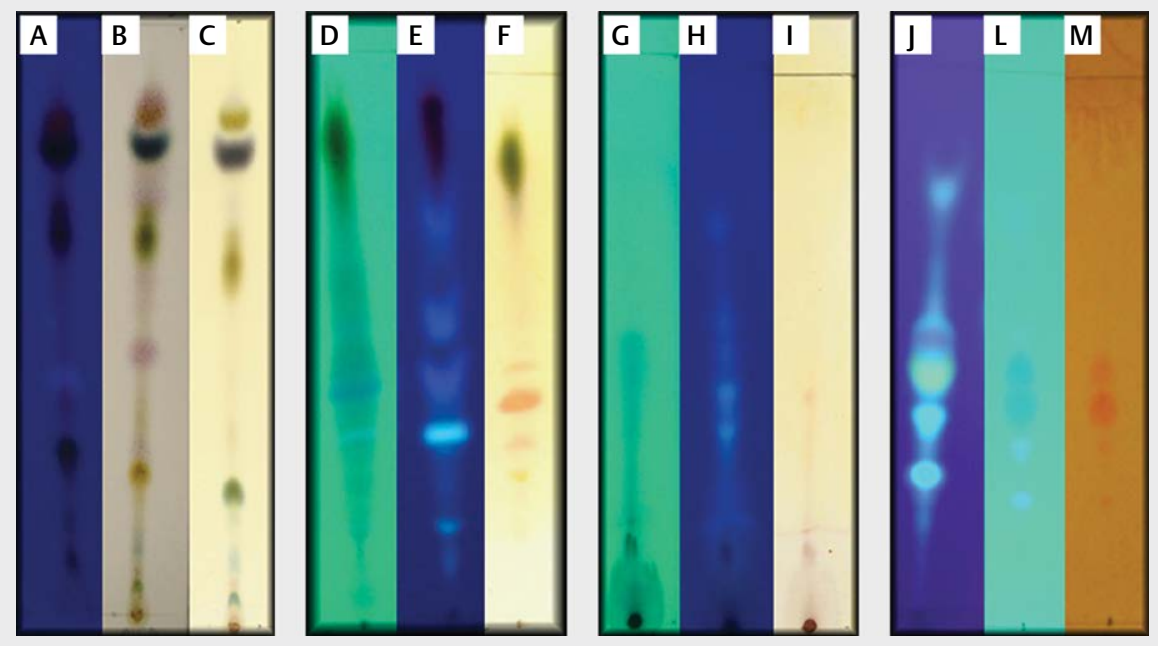

- Fig. 1 Thin-layer chromatography plates (silica gel 60 F254) of dichloromethane (DE, a-c), ethanolic (EE, d-e), aqueous (AE, g-i) extracts of Boehmeria caudata aerial parts and alkaloid rich fraction (AEF, j-m). Stationary phase: Mobile phase: dichloromethane/methanol (97:3, for DE) and butanol/acetic acid/distilled water (4:1:5, for EE, AE and AEF). Detection: under UV light (254 nm: D, G and L; $366 \mathrm{~nm}$ : A, E, H and J); Anisaldehyde (B) and Dragendorff (C, F, I and M) solutions.

less, when administrated via the i.p. route, $\mathrm{EE}\left(500 \mathrm{mg} \mathrm{kg}^{-1}\right)$ promoted depression, piloerection, tachypnea, and palpebral ptosis up to $4 \mathrm{~h}$ after administration, which suggested central nervous system effects. After $24 \mathrm{~h}$, the EE-treated mice showed normal behavior, which persisted throughout the experiment. In addition, at a higher dose $\left(1000 \mathrm{mg} \mathrm{kg}^{-1}\right.$, i.p.), EE promoted signs and symptoms of central nervous system depression, which resulted in the death of mice within the first $24 \mathrm{~h}$. Based on these results, we chose $150 \mathrm{mg} \mathrm{kg}^{-1}$ (30\% of the lower toxic dose on acute evaluation) of $\mathrm{EE}$ as the highest dose on the pharmacological experiments using the i.p. route.

In the same manner, after oral treatment, EE at $1000 \mathrm{mg} \mathrm{kg}^{-1}$ produced piloerection, tachypnea, and palpebral ptosis in mice during the first $4 \mathrm{~h}$ after treatment. All these symptoms disappeared after $24 \mathrm{~h}$, with mice exhibiting normal behavior during the following 14 days. Thus, to avoid possible cumulative adverse effects, the highest dose on pharmacological assays of $\mathrm{EE}$ using the o.r. route was established as $300 \mathrm{mg} \mathrm{kg}^{-1}$ ( $30 \%$ of $1000 \mathrm{mg} \mathrm{kg}^{-1}$ ). The result also suggested that the toxic substances present in EE had low bioavailability by the o.r. route, not reaching a sufficient systemic concentration to trigger the physiological changes that led to the death of the mice when compared to $\mathrm{EE}$ administration via the i.p. route.

The antitumor activity of EE was evaluated by the Ehrlich solid tumor model, which is used for mouse experimentation worldwide [20]. Derived from murine breast adenocarcinoma with aggressive and fast-growing characteristics, the Ehrlich tumor cells can grow in ascitic and solid forms depending on the inoculation in cavities or tissue, respectively [21]. Therefore, EE treatment significantly decreased tumor growth by $48.51 \%\left[75 \mathrm{mg} \mathrm{kg}^{-1}\right.$, i.p., RTW $=0.00155 \pm 0.0006, \mathrm{p}<0.01]$ and $35.5 \%\left(150 \mathrm{mg} \mathrm{kg}^{-1}\right.$, i.p., RTW $=0.00194 \pm 0.0004, p<0.05)$ in comparison to vehicle-treated animals ( $R T W=0.00301 \pm 0.0007$ ), while doxorubicin promot- ed a reduction of $33.88 \%\left(3 \mathrm{mg} \mathrm{kg}^{-1}\right.$, RTW $=0.00199 \pm 0.0003$, $\mathrm{p}<0.05$. There was no statistically significant difference among the treated groups ( $\triangleright$ Fig. 2). Furthermore, EE doses did not produce any clinical signs of toxicity during treatment.

It is well known that Ehrlich cell growth generates a local inflammatory response characterized by increased vascular permeability, edema formation, cell migration, and recruitment of the immune response [21]. As we take the tumor microenvironment into consideration as a therapeutic target, EE was evaluated by two different inflammation models in mice. Since i.p. administration can induce the local inflammatory process, the o.r. route was chosen for these assays.

CG-induced paw edema is a well-established in vivo inflammation model, commonly used to evaluate the anti-edematous effect of natural products [22]. When injected, CG-induced inflammatory edema result in a sequential and integrated actions of several inflammatory mediators. Two hours after CG injection, there is the release of histamine, 5-hydroxytryptamine, bradykinin, and serotonin, among other substances. Afterwards, increased COX-2 expression and prostaglandin production, monocyte mobilization, macrophage migration, and nitric oxide production maintain the edema up to 4 to $6 \mathrm{~h}$ after CG injection [23, 24].

In this model, oral administration of EE inhibited CG-induced edema with an inverse dose-effect relationship ( $\vee$ Table 3 ). Thus, the major inhibitory effect of EE was observed at $75 \mathrm{mg} \mathrm{kg}^{-1}$, from the first hour of CG edema induction $(p<0.001)$, while at $150 \mathrm{mg}$ $\mathrm{kg}^{-1}$, the inhibitory effect of EE was significant only after $4 \mathrm{~h}$ of edema induction. Moreover, at $300 \mathrm{mg} \mathrm{kg}^{-1}$, EE had a slight increase in CG-induced edema $(\mathrm{p}<0.05)$ at $6 \mathrm{~h}$ in comparison to the vehicle group. As expected, dexamethasone (positive control) inhibited edema development in a significant manner in relation to the vehicle group $2 \mathrm{~h}$ after $\mathrm{CG}$ injection. 


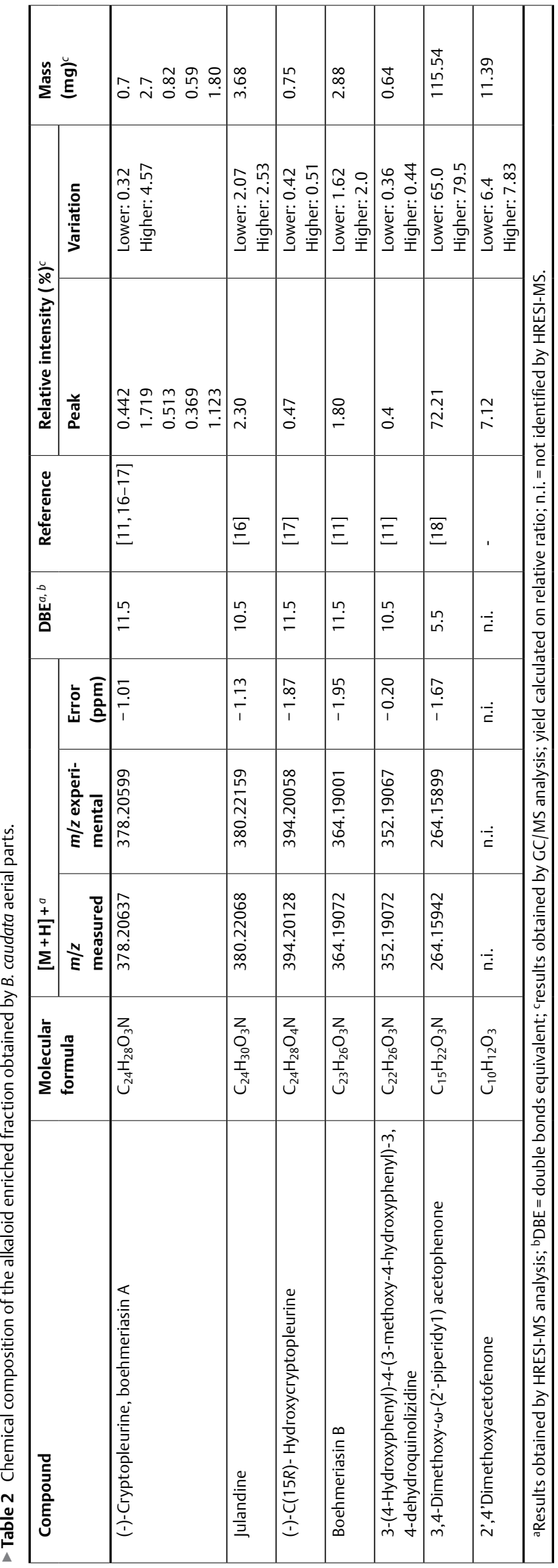

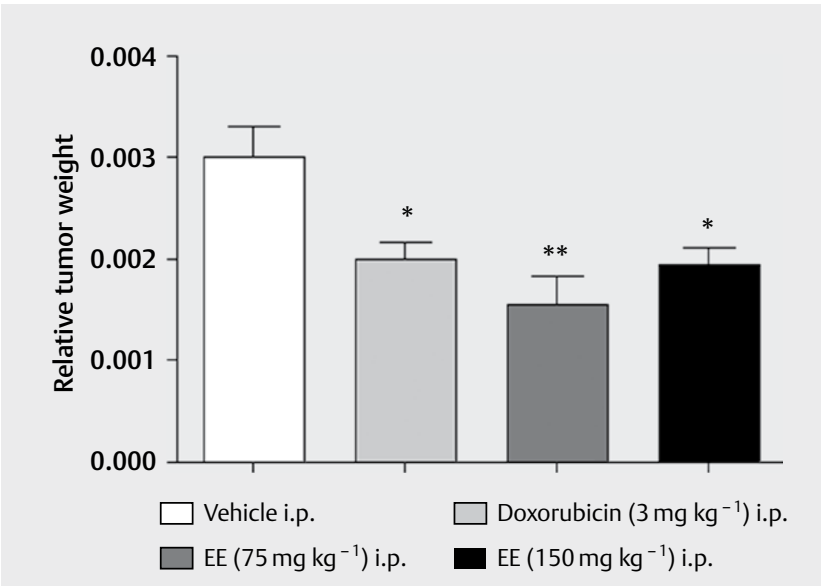

- Fig. 2 Relative weight of the Ehrlich solid tumor on the flank at the end of ten days of treatment with Boehmeria caudata leaves extract EE. (Relative tumor weight $=$ tumor mass weight/animal weight); results expressed as the mean \pm standard error media $(n=6$ male Balb/c mice per group). Groups: negative control (vehicle, PBS $\mathrm{pH} 7+$ tween $805 \%$ ), positive control (doxorubicin $3 \mathrm{mg} \mathrm{kg}^{-1}$ ) and EE (75 and $150 \mathrm{mg} \mathrm{kg}^{-1}$ ). EE: ethanolic extract. i.p.: intraperitoneal. * $\mathrm{p}<0.05,{ }^{*}{ }^{*} \mathrm{p}<0.01$, significant differences by statistical means in relation to vehicle group. (One-way ANOVA - followed by Tukey test).

The proinflammatory effect observed for $E E$ at $300 \mathrm{mg} \mathrm{kg}^{-1}$ could be attributed, in part, to the vesicant properties of cryptopleurine, which resemble those of nitrogen mustard [25], an alkylating agent used as a chemotherapeutic agent [26]. As the other identified phenanthroquinolizidine alkaloids shared chemical similarities with cryptopleurine, all theses alkaloids together in high dose, could present this vesicant properties and induced the edema. Other alkaloids used in cancer chemotherapy also have vesicant properties, such as vinca and taxol, which can cause severe irritation with vesicle formation, edema, and tissue destruction when in contact with intact skin [27].

Based on the report that the NSAIDs were unable to inhibit the first $2 \mathrm{~h}$ after $\mathrm{CG}$ edema induction [28], our results suggested that EE anti-edematogenic activity at $75 \mathrm{mg} \mathrm{kg}^{-1}$ can be partially explained as similar to that observed for steroidal anti-inflammatory drugs. To support this hypothesis, we decided to select the croton oil-induced ear edema model in mice.

Used as a screening assay for substances with potential anti-inflammatory action [29], the croton oil-induced ear edema model allowed for the evaluation of both topical and systemic routes of steroidal and nonsteroidal anti-inflammatory drugs [23, 30]. Croton oil, obtained from croton seeds (Croton tiglium L.), is a phorbol ester enriched phlogistic agent, with TPA as the major compound. Since phorbol esters activate the arachidonic acid inflammatory cascade through LOX and COX activities, substances with LOX and/ or COX inhibitory effects can be evaluated in this model [31].

As reported by our research group [32], independent of the administration route (o.r., i.p., or t.t. treatment), EE reduced croton oil-induced edema in mice ears by $41.39 \%(6.3 \mathrm{mg} \pm 1.7$, t.t. $)$, $57.48 \%(4.2 \mathrm{mg} \pm 1.34$, i.p.), and $62.02 \%(4.31 \mathrm{mg} \pm 0.71$, o.r. $)$ com- 

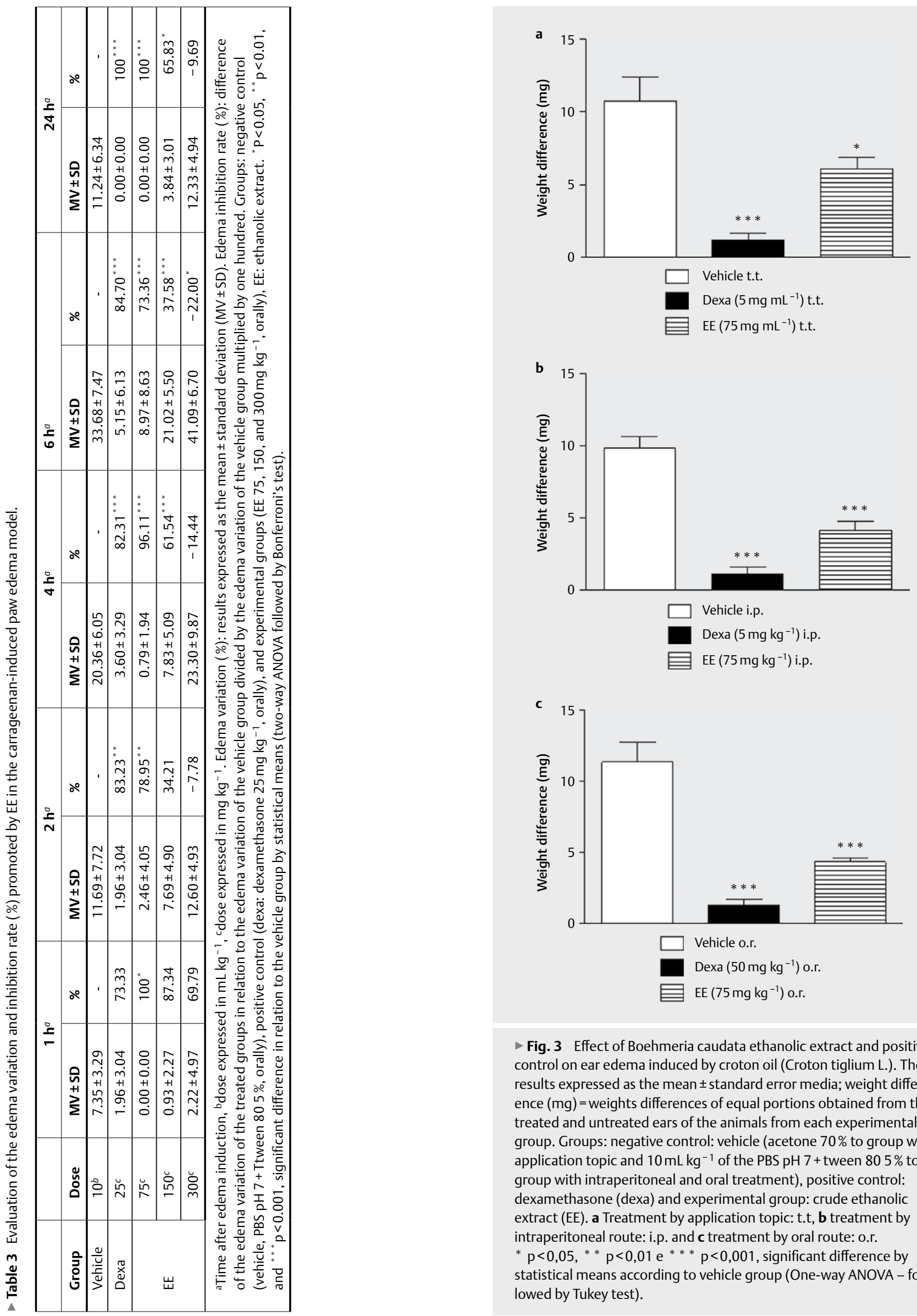

- Fig. 3 Effect of Boehmeria caudata ethanolic extract and positive control on ear edema induced by croton oil (Croton tiglium L.). The results expressed as the mean \pm standard error media; weight difference $(\mathrm{mg})=$ weights differences of equal portions obtained from the treated and untreated ears of the animals from each experimental group. Groups: negative control: vehicle (acetone $70 \%$ to group with application topic and $10 \mathrm{~mL} \mathrm{~kg}^{-1}$ of the PBS pH 7 + tween $805 \%$ to group with intraperitoneal and oral treatment), positive control: dexamethasone (dexa) and experimental group: crude ethanolic extract (EE). a Treatment by application topic: t.t, $\mathbf{b}$ treatment by intraperitoneal route: i.p. and $\mathbf{c}$ treatment by oral route: o.r.

${ }^{*} \mathrm{p}<0,05,{ }^{* *} \mathrm{p}<0,01 \mathrm{e}{ }^{* * *} \mathrm{p}<0,001$, significant difference by statistical means according to vehicle group (One-way ANOVA - followed by Tukey test). 
pared to the vehicle group $(10.75 \mathrm{mg} \pm 3.31$, t.t; $9.88 \mathrm{mg} \pm 1.78$, i.p.; and $11.35 \mathrm{mg} \pm 2.8$, o.r.). In all experiments, dexamethasone ( $5 \mathrm{mg} \mathrm{mL}^{-1}$, t.t.; $5 \mathrm{mg} \mathrm{kg}^{-1}$, i.p.; or $50 \mathrm{mg} \mathrm{kg}^{-1}$, o.r.) was able to inhibit from $88.05 \%(1.18 \mathrm{mg} \pm 1.13$, i.p. $)$ to $88.55 \%(1.23 \mathrm{mg} \pm 1.07$, t.t.) and $88.89 \%(1.26 \mathrm{mg} \pm 1.04$, o.r. $)$ of the croton oil-induced edema in mice ears ( $\triangleright$ Fig. $\mathbf{3})$.

According to Carlson et al. [31], coX inhibitor drugs such as indomethacin, aspirin, and piroxicam show no anti-inflammatory effect when administered orally by TPA-induced and arachidonic acid-induced ear edema assays, while mixed COX/LOX inhibitors as well as steroidal anti-inflammatory drugs are more effective by the oral route.

Analyzing our results, we observed that EE was more effective when administered by a systemic route than t.t. ( $>$ Fig. 3), suggesting that the mechanism of anti-inflammatory action of EE would involve a mixed inhibitory capacity (COX/LOX inhibitors) or an activity similar to steroidal anti-inflammatory drug. (phospholipases inhibitor), corroborating CG-induced paw edema results ( $\triangleright$ Table 3).

Therefore, blocking COX and/or LOX pathways could be a plausible approach for the inhibition of tumor progression. Some in vitro studies have demonstrated that simultaneous inhibition of COX and LOX pathways are more efficient in cell death induction in comparison to selective inhibition [33, 34].

In conclusion, the antitumor activity of EE from $B$. caudata aerial parts could be explained by the antiproliferative effects associated with the anti-inflammatory effects.

\section{Material and Methods}

\section{Chemical and equipment}

Dichloromethane and ethanol were purchased from Labsynth. Trichloroacetic acid, Tween 80, dexamethasone (purity $>90 \%$ ), DMSO, CG, and croton oil were obtained from Sigma-Aldrich. All solvents were of analytical grade. Culture medium RPMI 1640 and fetal bovine serum were from Gibco. Penicillin/streptomycin (1000 $\mathrm{U} / \mathrm{mL}: 1000 \mathrm{mg} / \mathrm{mL}$ ) was acquired from Vitrocell. Doxorubicin (doxorubicin chlorohydrate $50 \mathrm{mg}$; purity $>90 \%$ ) was purchased from Eurofarma. TLC plates using silica gel 60 (F254) were obtained from Merck. ESI-Obitrap (Q Exactive) was attained from Thermo Scientific Bremen, the mass detector (CG 6890N) was from Agilent, and the Plethysmometer apparatus (7140) was from Ugo Basile.

\section{Plant material}

The aerial parts of the $B$. caudata Sw. were collected at the CPQBA - UNICAMP experimental field, in which the botanical identification was performed by MSc Jorge Yoshio Tamashiro, researcher of the Department of Plant Biology, Institute of Biology/UNICAMP. A voucher specimen was deposited at the UNICAMP Herbarium under number UEC 107966. B. caudata is a Brazilian native genetic material. Hence, the present study had been approved by the Genetic Patrimony Management Board (CGEN/MMA) through the Access and Shipment Component of Genetic Heritage for scientific research purposes (number: 010672/2012-5).

\section{Extract preparation}

Milled dried aerial parts of $B$. caudata $(5 \mathrm{~g})$ were extracted with dichloromethane, $95 \%$ ethanol, and distilled water by a Soxhlet extraction system (1:5 plant:solvent ratio, w/v) in succession. After solvent evaporation under vacuum at $40^{\circ} \mathrm{C}$ and freeze-drying, the $\mathrm{DE}$ ( $5 \%$ yield), $\mathrm{EE}$ ( $4.6 \%$ yield), and $\mathrm{AE}$ ( $6.7 \%$ yield) were stored at $-20^{\circ} \mathrm{C}$ until further analysis.

\section{Acid-base extraction}

An aliquot of EE diluted in distillate water (1:4 plant:solvent ratio, $\mathrm{w} / \mathrm{v}$ ) was acidified with $10 \%$ hydrochloric acid until $\mathrm{pH} \approx 1$. After $24 \mathrm{~h}$ at $4^{\circ} \mathrm{C}$, the mixture was vacuum filtered to separate a dark green precipitate from the red supernatant in which was extracted by liquid-liquid partition with ethyl acetate (3:1, v/v, 3 times) affording the aqueous acidic solution (AAS), and the ethyl acetate solution. Furthermore, the AAS was partitioned with ethyl ether $(3: 1, v / v, 3$ times) providing ethyl ether solution, and the final aqueous acidic solution $\left(A A S_{F}\right)$. After $\mathrm{pH}$ adjustment $(\mathrm{pH} \approx 11$ ) with ammonium hydroxide, $\mathrm{AAS}_{\mathrm{F}}$ was partitioned with dichloromethane (3:1, v/v, 3 times) giving forth the aqueous basic and dichloromethane (DCM) solutions. After being washed with distilled water (3:1, $\mathrm{v} / \mathrm{v}, 3$ times) and filtered through anhydrous sodium sulfate, the DCM solution was evaporated to dryness under vacuum at $40^{\circ} \mathrm{C}$. After HRESI-MS analysis, the DCM fraction was renamed as AEF ( $0.9 \%$ yield).

\section{Thin-layer chromatography analyses}

$D E, E E, A E$, and AEF were analyzed by TLC plates with silica gel 60 as the stationary phase and two mobile phases [dichloromethane:methanol 97:3 (v/v) and BAW (butanol:acetic acid:distilled water $4: 1: 5, v / v)]$. After complete elution, the TLC plates were visualized under UV light ( 254 and $366 \mathrm{~nm}$ ) followed by detection with spray reagents anisaldehyde/sulfuric acid (lipophilic substances, sugars, and glycosides) and Dragendorff (nitrogen-containing compounds) [35].

\section{Characterization of the ethanolic extract and alkaloid enriched fraction by high-resolution electrospray ionization mass spectrometry}

One aliquot $(10 \mu \mathrm{L})$ of EE and $A E F$ solution $\left(20 \mathrm{mg} \mathrm{mL}^{-1}\right.$, in methanol) was diluted in separate methanol/water $(1: 1, v / v)$ with $0.1 \%$ formic acid ( $99 \%, 990 \mu \mathrm{L})$. To utilize one syringe pump, the sample solution was injected by direct infusion into the ESI-Obitrap mass spectrometer for positive ion mode ionization in which the total acquisition time for each spectrum was fixed at $1 \mathrm{~min}$. ESI-MS (full scan) spectra were acquired in the range of $\mathrm{m} / \mathrm{z} 150$ to 800 for the $\mathrm{EE}$, and the alkaloids were identified in the range of $200-400 \mathrm{~m} / \mathrm{z}$ of AEF. The ESI-MS/MS spectra were acquired with a collision energy of 10-40 eV. The general operating conditions of the equipment were: $3500 \mathrm{~V}$ of spray voltage, $320^{\circ} \mathrm{C}$ to capillary temperature, 10 psi of sheath gas pressure, and $50 \mathrm{~V}$ to S-lens. Data treatment was carried out using Xcalibur software. (Thermo Scientific).

\section{Alkaloid enriched fraction analysis by gas chromatography coupled to mass detector}

A sample $(1 \mu \mathrm{L})$ of AEF solution $\left(20 \mathrm{mg} \mathrm{mL}^{-1}\right)$ was subject to scientific analysis by capillary gas chromatography coupled to a mass 
selective detector, equipped with a silica column $(30 \mathrm{~m} \times 0.25 \mathrm{~mm}$, $\mathrm{HP}-5)$. The overall operating conditions of the equipment were: temperature of the injector: $250^{\circ} \mathrm{C}$; detector temperature: $300^{\circ} \mathrm{C}$; temperature program: $110(2 \mathrm{~min})-240^{\circ} \mathrm{C}, 5^{\circ} \mathrm{C} / \mathrm{min}, 240-300^{\circ} \mathrm{C}$, $10^{\circ} \mathrm{C} / \mathrm{min}$; with or without split ratio 1:100.

\section{Cell lines}

Human tumor cell lines [U251 (glioma), MCF-7 (breast), NCI-H460 (lung, non-small cells)] were provided by the National Cancer Institute. The non-tumor cell line HaCat (human keratinocytes) was donated by Professor Dr. Ricardo Della Coletta, FOP/ UNICAMP.

\section{Cell culture}

All cell lines were maintained in complete medium [RPMI 1640 medium supplemented with $5 \%$ fetal bovine serum and $1 \%$ of a penicillin:streptomycin mixture $\left.(\mathrm{v} / \mathrm{v})\left(1000 \mathrm{U} \mathrm{mL}^{-1}: 1000 \mathrm{~g} \mathrm{~mL}^{-1}\right)\right]$. For incubation conditions, the temperature was set at $37^{\circ} \mathrm{C}$ in a humid atmosphere with $5 \%$ of $\mathrm{CO}_{2}$, and the in vitro experiments were conducted under the same conditions.

\section{In vitro antiproliferative activity assay}

Cells in 96-well plates ( $100 \mu \mathrm{L}$ cells/well) were exposed to sample concentrations $\left(0.25,2.5,25\right.$, and $250 \mu \mathrm{g} \mathrm{mL}^{-1}$ in DMSO/complete medium, in triplicate) for $48 \mathrm{~h}$. The final DMSO concentration ( $\leq$ $0.25 \%$ ) was unaffected by cell viability. Doxorubicin was the positive control (0.025; 0.25, 2.5 and $\left.25 \mathrm{\mu g} \mathrm{mL}^{-1}\right)$. Before (T0 plate) and after the sample addition (T1 plates), cells were fixed with $50 \%$ trichloroacetic acid, and cell proliferation was determined by spectrophotometric quantification $(540 \mathrm{~nm}$ ) of the cellular protein content employing sulforhodamine B. Using the concentration-response curve for each cell line, TGI was determined through nonlinear regression analysis using ORIGIN 7.5 (OriginLab Corporation) software [21].

\section{Animals}

Experiments were conducted with Balb/c (17-25g, 60 days) and Swiss (25-35 g, 60 days) female mice obtained from the Multidisciplinary Center for Biological Investigation at Animals Sciences Laboratory (CEMIB-UNICAMP). Animals were maintained the Animal Facilities of Pharmacology and Toxicology Division, CPQBAUNICAMP, under controlled conditions [temperature $25 \pm 2{ }^{\circ} \mathrm{C}$ for $12 \mathrm{~h}$ light/dark cycle, with free access to food (Nuvilab) and tap water]. Animal care and research and animal sacrifice protocols were in accordance with the principles and guidelines adopted by the Brazilian College of Animal Experimentation (COBEA). The experimental procedures were approved by the Institute of Biology/ UNICAMP - Ethical Committee for Animal Research (3440-1 and 3441-1 were approved on July 7, 2014; 3391-1 and 3390-1 were approved on August 28, 2014). Euthanasia was performed by deep anesthesia followed by cervical dislocation.

\section{Sample preparation}

EE was diluted in PBS ( $\mathrm{pH} 7.0$ ) with $5 \%$ Tween 80 , considering the employment of different doses. Only for the tests with single oral administration $\left(\mathrm{V}_{\max }=10 \mathrm{~mL} \mathrm{~kg}{ }^{-1}\right)$, animals were kept in a fasting period of $4 \mathrm{~h}$ before treatment with free access to water, to allow total gastric emptying and no feeding interference in the active
Table 4 Group distribution in the croton oil-induced ear edema assay in mice.

\begin{tabular}{|l|l|l|l|}
\hline $\begin{array}{l}\text { Route of adminis- } \\
\text { tration }\end{array}$ & Groups $^{a}$ & & Vehicle $^{b}$ \\
\hline Topical & $\begin{array}{l}\text { Dexa- } \\
\text { metha- } \\
\text { sone }\end{array}$ & $\begin{array}{l}5 \mathrm{mg} \mathrm{mL} \\
\text { Oral }\end{array}$ & $\begin{array}{l}75 \mathrm{mg} \\
\mathrm{mL}^{-1}\end{array}$ \\
\hline Intraperitoneal & $10 \mathrm{~mL} \mathrm{~kg}$ & $50 \mathrm{mg} \mathrm{kg}^{-1}$ & $\begin{array}{l}75 \mathrm{mg} \\
\mathrm{kg}^{-1}\end{array}$ \\
\hline
\end{tabular}

an = 6 Balb/c mice/group; bnegative control (70\% acetone on topical administration and PBS with $5 \%$ Tween 80 by oral administration; cpositive control; dethanolic extract.

principles absorption. Moreover, all experimental models began $1 \mathrm{~h}$ after sample administration to ensure absorption and systemic distribution.

\section{Acute toxicity evaluation}

Swiss mice were distributed ( $\mathrm{n}=5$ animals/group) into negative control (vehicle, $10 \mathrm{~mL} \mathrm{~kg}^{-1}$ ) and experimental (EE, $1000 \mathrm{mg} \mathrm{kg}^{-1}$, o.r.; 500 and $1000 \mathrm{mg} \mathrm{kg}^{-1}$, i.p) groups. After administration, animals were observed during the first $4 \mathrm{~h}$, and daily for 14 days. Afterwards, all animals were euthanized by cervical dislocation [19].

\section{The Ehrlich solid tumor model}

Ehrlich tumor cells were maintained in the ascitic form by weekly i.p. transplantation in Swiss mice. For the experiments, the ascitic suspension was collected and the tumor cell suspension was prepared at a density of $5 \times 10^{6}$ cells/60 $\mathrm{L}$ /animal after cell viability evaluation with trypan blue.

Ehrlich cells suspension was inoculated subcutaneously in the flank of Balb/c mice ( $n=6$ animals/group, $60 \mu \mathrm{L} /$ animal). On the $3^{\text {rd }}$ day, animals with palpable tumors were randomly divided into negative control (vehicle, $10 \mathrm{~mL} \mathrm{~kg}^{-1}$, i.p.), positive control (doxorubicin, $3 \mathrm{mg} \mathrm{kg}^{-1}$, i.p.), and experimental groups (EE, 75 and $150 \mathrm{mg}$ $\mathrm{kg}^{-1}$, i.p.). The negative control and EE groups were treated every day, while the positive control group was treated every 2 days. On the $10^{\text {th }}$ day, animals were euthanized, and tumors were removed and weighted. The procedures used for this study were similar to those previously described [21].

\section{Carrageenan-induced paw edema}

Balb/c mice ( $n=6 /$ group) were weighed, randomly distributed, and orally treated with vehicle $\left(10 \mathrm{~mL} \mathrm{~kg}^{-1}\right.$, negative control), dexamethasone ( $25 \mathrm{mg} \mathrm{kg}^{-1}$, positive control) or $\operatorname{EE}(75,150$, and $\left.300 \mathrm{mg} \mathrm{kg}^{-1}\right)$. After $1 \mathrm{~h}$, inflammation was induced by carrageenan inoculation ( $3 \%$ in PBS, $30 \mu \mathrm{L} / \mathrm{paw}$ ) into the subplantar region of the right hind footpad. The hind paw volume was evaluated using a plethysmometer at 0 (basal volume), 1, 2, 4, 6, and $24 \mathrm{~h}$ after CG inoculation, and the edema volume was obtained by the difference between basal and experimental hind paw volumes. The procedures used for this study were similar to those described previously, with minor modifications $[10,36]$. 


\section{Croton oil-induced ear edema}

Balb/c mice ( $n=6$ animals/group) were weighed and distributed into the experimental groups ( $\triangleright$ Table 4 ). One hour after each treatment, mice received croton oil topical application $(20 \mu \mathrm{L} / \mathrm{ear}$, $5 \%$ in acetone $70 \%$ ) in the right ear, while the left ear was treated with $70 \%$ acetone $(20 \mu \mathrm{L} /$ ear). Four hours after croton oil application, the animals were euthanized, and the ear edema was determined by weight difference between the left and right ears [36].

\section{Statistical analysis}

The experimental results are expressed as the mean \pm standard error media (SEM) or mean \pm standard deviation (SD). Statistical significance was evaluated by analysis of variance (ANOVA), one-way or two-way, followed by Tukey's or Bonferroni's test in the order given using GraphPad Prism version 5.0 software. Statistical significance is represented by ${ }^{*} \mathrm{p}<0.05,{ }^{* *} \mathrm{p}<0.01$, and ${ }^{* * *} \mathrm{p}<0.001$.

\section{Supporting information}

The ethanolic extract and alkaloid enriched fraction spectrum by HRESI-MS is available as Supporting Information (Fig. 1S and Fig. 2S).

\section{Acknowledgments}

The authors would like to thank the technical support offered by Sirlene Valério Tinti and Benício Pereira from CPQBA. Paula Pereira de Paiva was supported by the São Paulo Research Foundation (FAPESP) (\#2011/22458-3). Rafael Rosolen Teixeira Zafred, Fabiana Regina Nonato, João Ernesto de Carvalho, and Mary Ann Foglio thank the National Council for Scientific and Technological Development (CNPq) for scholarship (R.R. T. Z. and F. R. N.) and fellowship (J. E. C. and M. A. F.) support.

\section{Conflict of Interest}

The authors declare that they have no conflict of interest.

\section{References}

[1] Diakos Cl, Charles KA, McMillan DC, Stephen J Clarke. Cancer-related inflammation and treatment effectiveness. Lancet Oncol 2014; 15: e493-e503

[2] Abdul Wahab SM, Jantan I, Haque MA, Laiba Arshad. Exploring the leaves of Annona muricata L. as a source of potential anti-inflammatory and anticancer agents. Front Pharmacol 2018; 9: 661

[3] Ahmad W, Jantan I, SNA Bukhari. Tinospora crispa (L.) Hook. f. \& Thomson: A Review of Its Ethnobotanical, Phytochemical, and Pharmacological Aspects. Front Pharmacol 2016; 7: 59

[4] Ma JF, Wei PF, Guo C, Shi YP, Qiu LX, Wen LP. The Ethyl Acetate Extract of Gynura formosana Kitam. Leaves Inhibited Cervical Cancer Cell Proliferation via Induction of Autophagy. Biomed Res Int 2018; 2018: 4780612

[5] Pais VAA. Evaluation of anticancer activity in vivo and in vitro of medicinal plants from "Serra da Mantiqueira Paulista" [dissertation]. Campinas: Institute of Biology, University of Campinas; 2011

[6] Wilmot-Dear CM, Friis I. The New World species of Boehmeria and Pouzolzia (Urticaceae, tribus Boehmerieae). A taxonomic revision. Opera Botanica 1996; 129: 1-103
[7] Gaglioti AL. Urticaceae Juss. no Estado de São Paulo, Brasil [dissertation]. São Paulo: Instituto de Botânica da Secretaria de Estado do Meio Ambiente. 2011

[8] Hoffmann JJ, Luzbetak DJ, Torrance SJ, Cole JR. Cryptopleurine, cytotoxic agent from Boehmeria caudata (Urtiaceae) and Cryptocarya laevigata (Lauraceae). Phytochemistry 1977; 17: 1448

[9] Farnsworth NR, Hart NK, Johns SR, Lamberton JA, Messmer W. Alkaloids of Boehmeria cylindrica (family Urticaceae): Identification of a cytotoxic agent, highly active against Eagle's 9KB carcinoma of the nasopharynx in cell culture, as crytopleurine. Aust J Chem 1969; 22: 1805-1807

[10] Lin CC, Yen MH, Lo TS, Lin CF. The anti-inflammatory and liver protective effects of Boehmeria nivea and B. nivea subsp. nippononivea in rats. Phytomedicine 1997; 4: 301-308

[11] Luo Y, Liu Y, Luo D, Gao X, Li B, Zang G. Cytotoxic alkaloids from Boehmeria siamensis. Planta Med 2003; 69: 842-845

[12] Wardihan, Rusdi M, Alam G, Lukman, Manggau M. Selective cytotoxicity evaluation in anticancer drug screening of Boehmeria virgata (Forst) Guill leaves to several human cell lines: Hela, Widr, T47D and Vero. Dhaka Univ J Pharm Sci 2013; 12: 87-90

[13] Sung M], Davaatseren M, Kim SH, Kim M], Hwang J-T. Boehmeria nivea attenuates LPS induced inflammatory markers by inhibiting p38 and JNK phosphorylations in RAW264.7 macrophages. Pharm Biol 2013; 51: $1131-1136$

[14] Lee AY, Wang X, Lee DG, Kim Y-M, Jung Y-S, Kim HB, Kim HY, Cho E], Lee $S$. Various Biological Activities of Ramie (Boehmeria nivea). Appl Biol Chem 2014; 57: 279-286

[15] Fouche G, Cragg GM, Pillay P, Kolesnikova N, Maharaj VJ, Senabe J. In vitro anticancer screening of South African plants. J Ethnopharmacol 2008; 119: 455-461

[16] Al-Shamma A, Drake SD, Guagliardi LE, Mitscher LA, Swayze JK. Antimicrobial alkaloids from Boehmeria cylindrical. Phytochemistry 1982; 21: 485-487

[17] Krmpotic E, Farnsworth NR, Messmer WM. Cryptopleurine, an active antiviral alkaloid from Boehmeria cylindrical (L.) Sw. (Urticaceae). J Pharm Sci 1972; 61: 1508-1509

[18] Jin HR, Jin SZ, Cai XF, Li D, Wu X, Nan JX, Lee J], Jin X. Cryptopleurine targets NF-kB pathway, leading to inhibition of gene products associated with cell survival, proliferation, invasion and angiogenesis. PLoS One 2012; 7: e40355

[19] OECD. OCDE Guidelines for the Testing of Chemicals, Acute Oral Toxicity - up-and-down procedure (UDP). Available at: https://www. oecd.org/env/test-no-425-acute-oral-toxicity-up-and-down-procedure-9789264071049-en.htm Accessed January, 252014.

[20] Meral I, Pala M, Akbas F, Ustunova S, Yildiz C, Demirel MH. Effects of thymoquinone on liver miRNAs and oxidative stress in Ehrlich acid mouse solid tumor model. Biotech Histochem. 2018; 93: 301-308

[21] Iwamoto LH, Vendramini-Costa DB, Monteiro PA, Ruiz AL, Sousa IM, Foglio MA, de Carvalho JE, Rodrigues RAF. Anticancer and Anti-Inflammatory Activities of a Standardized Dichloromethane Extract from Piper umbellatum L. Leaves. Evid Based Complement Alternat Med 2015; 2015: 948737

[22] Fabri RL, Garcia RA, Florêncio JR, Pinto NCC, de Oliveira LG, Aguiar JAK, Ribeiro A, Scio E. Anti-inflammatory and antioxidative effects of the methanolic extract of the aerial parts of Mitracarpus frigidusin established animal models. J Pharm Pharmacol 2014; 66: 722-732

[23] Lapa A], Souccar C, Lima-Landman MTR, Castro MAS, Lima TCM. Métodos de avaliação da atividade farmacológica de plantas medicinais, 5a. ed. São Paulo Setor de Produtos Naturais, Departamento de Farmacologia, UNIFESP/EPM. 2007; 119p

[24] Pedernera AM, Guardia T, Calderón CEG, Rotelli AE, de la Rocha NE, Saad JR, Verrilli MA, Aseff SG, Pelzer LE. Anti-inflammatory effect of Acacia visco extracts in animal models. Inflammopharmacology 2010; 18: $253-260$ 
[25] Fridrichsons J. Mathieson AMCL. Structure of a derivative of cryptopleurine. Nature 1954; 173: 732-733

[26] Almeida VL, Leitão A, Reina LCB, Montanari A, Donnici CL, Lopes MTR. Câncer e a agentes antineoplásicos ciclo-celular específicos e ciclo-celular não específico que interagem com o DNA: uma introdução. Quim Nova 2005; 28: 118-129

[27] Brunherotti MR. Extravasation intervention of vesicant chemotherapeutic agents: Integrative literature review [dissertation]. Ribeirão Preto Escola de Enfermagem de Ribeirão Preto, Ribeirão Preto, Universidade de São Paulo. 2007

[28] Prajapati VD, Maheriya PM, Jani GK, Solanki HK. Carrageenan: A natural seaweed polysaccharide and its applications. Carbohydr Polym 2014; 105: 97-112

[29] Murakawa M, Yamaoka K, Tanaka Y, Fukuda Y. Involvement of tumor necrosis factor (TNF)- $\alpha$ in phorbol ester 12-O-tetradecanoylphorbol13-acetate (TPA)-induced skin edema in mice. Biochem Pharmacol 2006; 71: 1331-1336

[30] Tubaro A, Dri P, Melato M, Mulas G, Bianchi P, Del Negro P, Della Loggia R. Agents Actions 1996; 19: 371-373
[31] Carlson RP, O’Neill-Davis L, Chang J, Lewis AJ. Modulation of mouse ear oedema by cyclooxygenase and lipoxygenase inhibitors and other pharmacologic agents. Agents Actions 1985; 17: 197-206

[32] Paiva P, Nonato F, Zafred R, Sousa I, Ruiz AL, Carvalho JE. Anti-inflammatory activity of Boehmeria caudata sw. (Urticaceae) crude ethanol extract on croton oil mouse ear oedema. Planta Med 2014; 80: 1528

[33] Schneider C, Pozzi A. Cyclooxygenases and lipoxygenases in cancer. Cancer Metastasis Rev 2011; 30: 277-294

[34] Greene ER, Huang S, Serhan CN, Panigrahy D. Regulation of inflammation in cancer by eicosanoids. Prostaglandins Other Lipid Mediat 2011; 96: $27-36$

[35] Gibbons S. An introduction to planar chromatography and its application to natural products isolation. In: Sarker SD, Nahar L, (Editors.) Natural Products Isolation - Methods and Protocols. 3 ed. New York: Humana Press (Springer); 2012: 117-154

[36] de Oliveira JF, Nonato FR, Zafred RRT, Leite NMSL, Ruiz ALTG, Carvalho JE, Silva AL, Moura RO, Lima MCA. Evaluation of anti-inflammatory effect of derivative (E)-N-(4- bromophenyl)-2-(thiophen-2-ylmethylene)thiosemicarbazone. Biomed Pharmacother 80: 2016; 388-392 